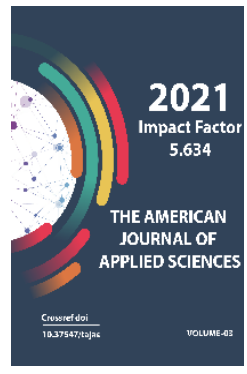

\title{
Mineral Fertilizers
}

Polvonov Khurshid Madaminovich

Fergana Polytechnic Institute, Uzbekistan

Journal Website:

http://usajournalshub.c om/index,php/tajas

Copyright: Original content from this work may be used under the terms of the creative commons attributes 4.0 licence.

\section{ABSTRACT}

Importance of mineral fertilizers. Mineral fertilizers and their types. Nitrogen fertilizers and their types. Potassium and phosphorus fertilizers. General rules of application of mineral fertilizers.

\section{KEYWORDS}

Mineral fertilizers, nitrogen, potassium, phosphorus, trace elements, natural salts, sodium nitrate, and soil.

\section{INTRODUCTION}

About $10 \%$ of the earth's surface is planted with agricultural crops. It is impossible to expand the sown areas further. But the population of our planet is constantly growing, and it is necessary to further increase productivity to provide them with food. One of the most important ways to do this is to use mineral fertilizers. Fertilizer is a substance designed to improve plant nutrition and increase soil fertility.

Mineral fertilizers are salts and other inorganic, industrial and mineral products that contain elements necessary for plant development and 
soil fertility, used for sustainable and high yields.

More than 70 chemical elements are involved in the formation of plant tissue, its growth and development. The most important of these are carbon, oxygen, and hydrogen, which make up $90 \%$ of the dry mass of a plant; Nitrogen, phosphorus, potassium, magnesium, sulfur, sodium and calcium make up $8-9 \%$ of the plant mass. These ten elements are called macronutrients. The remaining $1-2 \%$ is iron, copper, manganese, zinc, molybdenum, cobalt and others. These plants need very small amounts (0.001-0.0001\%). That is why they are called trace elements.

Plants get most of the carbon, oxygen, and hydrogen from these elements from air and water, while they get the rest from the soil. Most of the elements that the plant receives do not return to the soil, but are removed by the crop. For example, 1 ton of corn carries $14 \mathrm{~kg}$ of nitrogen, $2.5 \mathrm{~kg}$ of phosphorus, $3.5 \mathrm{~kg}$ of potassium, $1.5 \mathrm{~kg}$ of sulfur from the soil. Much of the soil elements are washed away by water and interact with soil components to make the plant unable to assimilate. As a result, there is a shortage of plant nutrients in arable lands, soil fertility decreases. If these lost elements are not replaced by fertilizing the soil, the yield will decrease sharply.

Mineral fertilizers have been spread since the 19th century. From the middle of the 20th century, the production and application of mineral fertilizers grew rapidly. Prior to that, manure, ash and other wastes were used as fertilizers. Mineral fertilizers have a strong effect on the soil (its physical, chemical and biological properties); they enrich the soil with nutrients, change the reaction of the soil solution, affect microbiological processes, and so on. When mineral fertilizers are applied to the soil, mainly due to root nutrition, they actively affect the growth and development of plants and, consequently, the overall biological productivity of fields and meadows. Mineral fertilizers increase crop yields, improve quality: increase the technological properties of cotton, hemp, flax and crop fiber, sugar beet, grape sugar, potato starch, grain protein. Mineral fertilizers give better results when used in combination with organic fertilizers. For agronomic purposes, mineral fertilizers are divided into direct and indirect fertilizers. Directly applied fertilizers contain elements such as nitrogen, phosphorus, potassium, as well as magnesium, boron, zinc, copper, molybdenum, manganese, and sulfur, which are necessary for plant nutrition. Fertilizers in this group are mainly single-nutrient, nitrogen, phosphorus or potassium, and complex, mixed and complex fertilizers. Mixed mineral fertilizers are made in the factory or on the farm by mixing several different fertilizers, and complex fertilizers are made in the factory. Indirectly used mineral fertilizers (lime fertilizers, gypsum, etc.) are mainly used to improve the agrochemical and physicochemical properties of the soil removed.

The effectiveness of mineral fertilizers depends on the biological properties of the plant, the rate of fertilizer applied each time, its use in combination with organic fertilizers, the quality of applied agro-technical measures, and so on. Proper determination of the rate of mineral fertilizers applied to the soil for maximum yield from agricultural crops is important in the use of mineral fertilizers, and this rate is determined by the amount of pure active nutrients in the fertilizer per $\mathrm{kg} / \mathrm{ha}$. Mineral fertilizers should be applied taking into 
account the biological properties of the plant, their nutrient requirements, the amount of nutrients in the soil, the nature of the fertilizers used, the conditions necessary for normal plant growth and development. It is applied in early spring (basic fertilization), during planting and during the growing season (feeding plants). Improper use of mineral fertilizers can cause significant damage to the biocenosis and environmental pollution. Mineral fertilizers undergo various changes in the soil, which affect the solubility of nutrients, their movement in the soil and their absorption by plants.

Mineral fertilizers are divided into nitrogen, potassium and phosphorus. This is due to the fact that the leading elements of nutrition that have a dominant effect on the proper growth and development of plants are nitrogen, potassium and phosphorus. Of course, no one underestimates the importance of other elements such as magnesium, zinc, iron, but the three things listed are the basis. Let's look at them in order.

\section{Nitrogen fertilizers. Signs of nitrogen deficiency in the soil}

Often a lack of nitrogen fertilizers occurs in plants in the spring. Their growth is controlled, the effects are weakly formed, the leaves are atypically small, and the inflorescences are small. In the next stage, this problem is recognized by the illumination of the leaves, starting from the veins and surrounding tissues. Typically, this effect manifests itself in the lower part of the plant and gradually rises, completely illuminated leaves fall.

\section{Types of nitrogen fertilizers}

The most common nitrogen fertilizers are ammonium nitrate and urea. However, this group includes ammonium sulfate and calcium nitrate and sodium nitrate and azoth's and nitroammofosk and amorphous and ammonium phosphate. They all have a different composition and have different effects on the soil and crops. Thus, urea acidifies the soil, while calcium, sodium, and ammonium nitrate alkalize it.

\section{Methods of application}

Nitrogen fertilizers are the most dangerous of all mineral fertilizers. This is because as they multiply, plants accumulate large amounts of nitrates in their tissues. Therefore, nitrogen should be used very carefully depending on soil composition, nutrient yield and fertilizer center.

Since nitrogen has the ability to evaporate, nitrogen fertilizers should be made as soon as it is added to the soil. It is not practical to fertilize the soil with nitrogen in the fall, as most of it is washed away by rain during the spring planting period.

\section{Types of potassium fertilizers.}

On sale we can find several types of potassium fertilizers, in particular: potassium nitrate, potassium chloride (good for spinach and celery), potassium sulfate (also contains sulfur), kalimagnesia (potassium + magnesium), kalimag. In addition, potassium is part of complex fertilizers such as nitroammofosko, nitro fox, carboammophosk.

\section{Methods of application of potassium fertilizers.}

The use of potassium fertilizers should be in accordance with the instructions attached to them - this simplifies the approach to feeding and gives a reliable result. They should be immediately covered with soil: in the fall - to 
dig, in the spring to plant seedlings. Potassium chloride is introduced only in the fall, as it allows the chlorine to be stored in the weather.

Root crops are best suited for the application of potassium fertilizers - under them should be applied high doses of potassium.

\section{Types of phosphate fertilizers.}

One of the most common phosphate fertilizers used in any soil is superphosphate, potassium monophosphate reacts very quickly and is a very good option for phosphorus.

\section{General rules of application of mineral fertilizers.}

It is important to understand that mineral fertilizers can be used both as a basic fertilizer (for digging the soil in the fall, or before planting in the spring) and as an option for spring-summer fertilization. Each of them has its own dating rules and norms, but there are general recommendations that cannot be ignored.

1. Under no circumstances should fertilizers be grown in containers used for cooking.

2. It is better to store fertilizers in vacuum packaging.

3. If mineral fertilizers are cooked, they should be crushed or sieved before application, with a hole diameter of 3 to 5 $\mathrm{mm}$.

4. The application of mineral fertilizers to the crop should not exceed the dose recommended by the manufacturer, but it is better to calculate the required rate with laboratory testing of the soil. In general, the amount of nitrogen fertilizers: ammonium nitrate - 10 - $25 \mathrm{~g}$ per square meter, urea spraying - $5 \mathrm{~g}$ per 10 liters of water; potassium fertilizers: potassium chloride - 20 - $40 \mathrm{~g}$ per square meter (as a basic fertilizer), for top dressing of leaves with potassium salt - $50 \mathrm{~g}$ per 10 liters of water; phosphorous ores: potassium monophosphate - 20 g per 10 l of water, for a leafy top sheet with superphosphate - 50 g per 10 l of water.

5. If high burning is done through the soil, care should be taken not to let the solution fall on the vegetative mass of the fertilized crop, or after high burning, wash the plants thoroughly with water.

6. Fertilizers applied in dry form, as well as nitrogen and potassium fertilizers should be immediately absorbed into the upper part of the soil, but they should not be too deep for the main mass of roots.

7. To soften the mineral fertilizer concentrate introduced into the soil, it should be thoroughly moistened before applying it.

8. If there is a lack of nitrogen in the soil, then phosphorus and potassium fertilizers should be applied only in combination with this missing element, otherwise they will not give the expected result.

9. If there is clay soil - the dose of fertilizer should be slightly increased; sand decreases, but increases the number of fertilizers. It is better to choose superphosphate from phosphate fertilizers for clay soils; any phosphate fertilizers are suitable for sandy soils.

10. In areas with high rainfall (medium branch) one-third of the main fertilizer is used for direct sowing of seeds or planting holes in the soil and sprinkling in the grooves is recommended. To ensure that the plants do not accept root rot, the included composition should be thoroughly mixed with the ground. 
11. The greatest effect in increasing soil fertility can be obtained by alternating mineral and organic fertilizers.

12. If the seedlings in the ground are so numerous that they are covered, the best option for the best dressing would be the best dressing on the leaves (leaves).

13. Top dressing of leaves is carried out on young leaves in spring. Root dressing with potassium fertilizers is carried out in the fall, covering the fertilizer to a depth of 10 $\mathrm{cm}$.

14. The application of mineral fertilizers as the main fertilizer is carried out by spreading it on the surface and forcibly adding it to the soil.

15. If mineral fertilizers are applied to the soil together with organic fertilizers and this is the most effective method, the dose of mineral fertilizers should be reduced by one third.

\section{CONCLUSION}

In conclusion, in order to increase the efficiency of the applied mineral fertilizers, proper organization of storage, prevention of waste when transporting them from one place to another, the specific physical properties of mineral fertilizers, chemical and mechanical properties. Such properties include water solubility, hygroscopicity, viscosity, moisture content, grain composition, as well as grain strength, etc. of mineral fertilizers. When storing mineral fertilizers, it is necessary to know a number of properties, such as their density, whether they are hazardous to fire and explosion or acid, and the release of ammonia.

\section{REFERENCES}

1. Pichurin.G.V. "Chemistry and everyday life of man" -M.: <<Drofa >>, 2004
2. Kuznesova.N. Ye " Chemistry " -M.: <<Vent Ana-Graf $>, 2002$

3. Madaminovich Polvonov Xurshid. Chemical metals and their working. ACADEMICIA: An International Multidisciplinary Research Journal. Year : 2020, Volume : 10, Issue : 11 First page : ( 781) Last page : (783) Print ISSN : 0000-0000. Online ISSN : 2249-7137. Article DOI : $10.5958 / 2249-$ 7137.2020.01432.9

4. Полвонов Х.М., Хамдамова Ш.Ш., Давлятова З.М., Ибрагимова Г.О. Физико-химическое обоснование процесса получения хлорат-кальциевого дефолианта с использованием отходов содового производства // Universum: технические науки. 2019. №11(68).URL:https://cyberleninka.ru/article/n/f iziko-himicheskoe-obosnovanie-protsessapolucheniya-hlorat-kaltsievogo-defoliantas-ispolzovaniem -othodov-sodovogoproizvodstva.

5. Домуладжанов И.Х., Махмудов С.Ю., Домуладжанова Ш.И., Полвонов Х.М. Нормативы предельно допустимых выбросов вредных веществ в атмосферу от Кувасайского подсобного предприятия железобетонных изделий // Universum: технические науки. 2020. №41 (73).

URL: https://cyberleninka.ru/article/n/normativy -predelno-dopustimyh-vybrosov-vrednyhveschestv-v-atmosferu-ot-kuvasayskogopodsobnogo-predpriyatiyazhelezobetonnyh-izdeliy.

6. Дадакузиев М.Р., Махмудов С.Ю. Защита гражданского населения при чрезвычайных ситуациях в Республике Узбекистан // Universum: технические науки. 2019. №12-1 (69). URL: https://cyberleninka.ru/article/n/zaschita- 
grazhdanskogo-naseleniya-prichrezvy-

chaynyh-situatsiyah-v-respublike-

uzbekistan.

7. Домуладжанов И.Х., Махмудов С.Ю., Дадакузиев М.Р. Предельно-допустимые стоки (ПДС) загрязняющих веществ в водные объекты // Universum: технические науки. 2020. №7-1 (76). URL: https://cyberleninka.ru/ article/n/predelnodopustimye-stoki-pds-zagryaznyayuschihveschestv-v-vodnyeobekty.

8. Махмудов С.Ю. Проблемы преподавания безопасности жизнедеятельности в вузах // Достижения науки и образования. 2017. №2 (15). URL: https://cyberleninka.ru/article/n/problemyprepodavaniya-bezopasnostizhiznedeyatelnosti-v-vuzah (дата обращения: 08.04.2021).

9. Махмудов С.Ю., Домуладжанов И.Х., Домуладжанова Ш.И. Выбор места строительства промышленного объекта с учетом климатических условий города Кувасая // Universum: технические науки : электрон. научн. журн. 2020. №4 (73).URL:https://7universum.com/ru/tech/a rchive/item/9316.

10. Содиқов, У. Х., \& Полвонов, Х. М. (2020). Ўқитишнинг замонавий усуллари. International journal of discourse on innovation, integration and education, 1(5), 205-207.

11. www.wikipedia.ru

12. www.ziyonet.uz 